\begin{tabular}{|l|l|l||}
\hline \multicolumn{2}{|c|}{ PublisherInfo } \\
\hline \hline PublisherName & $:$ & BioMed Central \\
\hline \hline PublisherLocation & $:$ & London \\
\hline \hline PublisherImprintName & $:$ & BioMed Central \\
\hline \hline
\end{tabular}

\title{
Mexico to open genome center
}

\begin{tabular}{|l|l|l||}
\hline \multicolumn{2}{|c|}{ ArticleInfo } \\
\hline \hline ArticleID & $:$ & 4990 \\
\hline \hline ArticleDOI & $:$ & $10.1186 /$ gb-spotlight-20040805-02 \\
\hline \hline ArticleCitationID & $:$ & spotlight-20040505-02 \\
\hline \hline ArticleSequenceNumber & $:$ & 53 \\
\hline \hline ArticleCategory & $:$ & Research news \\
\hline ArticleFirstPage & $:$ & 1 \\
\hline \hline ArticleLastPage & $:$ & 3 \\
\hline \hline & & RegistrationDate : 2004-8-5 \\
\hline ArticleHistory & $:$ & OnlineDate \\
\hline \hline ArticleCopyright & $:$ & BioMed Central Ltd2004-8-5 \\
\hline \hline ArticleGrants & $:$ & \\
\hline \hline ArticleContext & $:$ & 130595511 \\
\hline \hline
\end{tabular}


Mexican President Vicente Fox on July 19 approved the construction of the 2.4-billion peso (USD $\$ 196$ million) National Institute of Genomic Medicine (INMEGEN) in Mexico City, which is expected to open its first units later this year.

"We now join the nations using science and high technology to protect their population's health," Fox said in a statement. "We cannot afford the luxury of not joining this knowledge revolution because the health and well being of future generations is at stake."

Unique to Latin America, INMEGEN will focus on research programs devoted to the health problems of the Mexican population. Initial research will focus on metabolic diseases (diabetes and obesity), infectious and cardiovascular diseases, cancer, pharmacogenomics, and population genomics. It will be the 11th Mexican national health institute.

INMEGEN director Gerardo Jimenez-Sanchez, currently a visiting biomedical scientist at Johns Hopkins University, told us that in initial studies, it was clear that Mexico's demographics were based on an admixture of more than 65 native groups and a population from Spain.

"It's clear that Mexico needs to develop genomic medicine for the Mexican population" so that it does not have to depend on importing technology and scientific knowledge, Jimenez-Sanchez said.

When the Mexican Congress approved INMEGEN in April, lawmakers amended the laws governing the health institutes to allow embryonic stem cell research and therapeutic cloning. In a press conference on July 19, Juan Pedro Laclette, director of the Biomedical Research Institute at the Autonomous University of Mexico, said that "[when the reforms were approved], the creation of INMEGEN and therapeutic cloning were associated, yet both subjects are totally independent." But Jimenez-Sanchez said that INMEGEN researchers will not work with human embryos.

The Mexican Congress has approved only 150 million pesos for the construction of INMEGEN, and not everyone is convinced that the government will be able to provide the majority of the 2.4 billion pesos as planned.

"We had to wait 20 years to get a big research institute," Laclette told us. "I hope we will not have to wait another 20 years for INMEGEN to be constructed." A philanthropic foundation has donated 30 million pesos, and other funding is expected to come from the pharmaceutical industry.

The permanent 40,000 -square meter building is scheduled to be ready by late 2006 . Temporary 3000-square meter facilities - including six research labs, three high-technology units (genotyping, expression analysis, and bioinformatics), and teaching facilities - will open by the end of this year. INMEGEN now offers three graduate courses, Jimenez-Sanchez said.

Jimenez-Sanchez said that the new institute would soon be recruiting scientists from around the world, and has already attracted 120 candidates for available positions. 
Francis Collins, director of the National Human Genome Research Institute at the US National Institutes of Health, congratulated the Mexican leadership "for their remarkable vision and commitment in establishing this center." Collins told us that when he visited Mexico 2 years ago, he "came away with a strong sense of the compelling opportunity that exists there for research into genomic medicine."

Collins said that "there may well be genetic contributions to illness that are especially relevant to the Mexican populations."

"Most common diseases are due to an interaction between genes and environment and the environment in Mexico cannot be assumed to be same as elsewhere," Collins said. "It will only be possible to find out whether the genetic makeup of Mexican people is different from that of other populations by conducting cutting edge research in Mexico."

Asked whether it would be advisable to conduct similar initiatives in other Latin-American countries, Collins said, "Yes, by all means."

"To the extent possible, every nation should try to devote some resources to an exploration of these opportunities and to building strength in genomic research," Collins said. "That will both lead to medical advances and will stimulate the economy."

INMEGEN will host the first National Congress of Genomic Medicine from August 25 to 27.

\section{References}

1. National Institute of Genomic Medicine, [http://www.inmegen.org.mx]

2. National Congress of Genomic Medicine, [http://www.inmegen.org.mx/Congreso_Genomica/PDFs/ posteringles.PDF] 